\title{
Beyond cinema: Daphne du Maurier's intermedial experiments in 'The Little Photographer’ (1952)
}

\begin{abstract}
Among the short stories du Maurier wrote, 'The Birds' and 'Don't Look Now' stand out. The first has famously been singled out by Alfred Hitchcock and the second by Nicolas Roeg for their respective film adaptations. The fate of these two short stories confirms Elizabeth Bowen's statement according to which the short story, apart from being close to other literary genres, such as poetry and drama, developed alongside cinema. Although du Maurier has often been acclaimed as a peerless storyteller, critics have generally focused on these two short stories, especially 'The Birds', and almost entirely neglected the others. This article takes a close look at 'The Little Photographer' (1952) and explores its affinities with other art forms than cinema, namely, photography. Beyond the motif of photography and the visual qualities of the narrative, the mediating function of photography within the narrative will first be analysed. The manipulative skills of the photographer and the narrator will then be confronted and the dialogue between the art of photography and writing explored. Finally, du Maurier's ability to work across media will be shown to reverberate on her perception and (re)definition of modernism.
\end{abstract}

\section{KEYWORDS}

Daphne du Maurier 'The Little

Photographer' photography short story intermediality mediation intertextuality modernism 
1. See the back cover to the nyrb edition of 'Don't Look Now'.

2. So far and according to MLA, about thirty articles have been published on 'The Birds' and 'Don't Look Now'.

3. See also on 'Monte Verità', another neglected short story by du Maurier, Slavoj Zižek, 'Are we allowed to enjoy Daphnée [sic] du Maurier?' and Christine Reynier's 'The outrageousness of outrage in Daphne du Maurier's “Monte verità"'.

4. All references will be to the 2004 Virago edition.

5. Rajewsky writes that intermediality coming from literary studies 'primarily emphasise[s] the forms and functions of intermedial practices in given media products or medial constellations' (2005: 49). She further notes that 'intermedial references tend to be marginalized by all those approaches that restrict the quality of a "genuine" intermediality to configurations materially constituted by more than one medium' (Rajewsky 2005: 59) but demonstrates the importance of such a form of intermediality.
Among the short stories Daphne du Maurier wrote, 'The Birds' ([1952] 2004) and 'Don't Look Now' (1971) stand out. The first has famously been singled out by Alfred Hitchcock and the second by Nicolas Roeg for their respective film adaptations. The fate of these two short stories confirms Elizabeth Bowen's statement, according to which the short story, apart from being close to other literary genres, such as poetry and drama, developed alongside cinema:

The short story is a young art: as we now know it, it is the child of this century. Poetic tautness and clarity are so essential to it that it may be said to stand at the edge of prose; in its use of action it is nearer to drama than to the novel. The cinema, itself busy with a technique, is of the same generation: in the last thirty years the two arts have been accelerating together. They have affinities [...] the disoriented romanticism of the age.

(Bowen [1936] 1950: 38)

Although du Maurier has often been acclaimed as a 'peerless storyteller', ${ }^{1}$ critics have generally focused on these two short stories, especially 'The Birds', and almost entirely neglected the others. Only recently have Emma Liggins, Andrew Maunder and Ruth Robbins drawn attention to du Maurier as a writer of short fiction who crosses genres and mixes them up, blurring the line between high- and middle-brow form.

In a short chapter devoted to The Apple Tree ([1952] 2004), they show that the short story bears the traces of the combined influence of the weird tales of the Victorian period and Katherine Mansfield's modernism in 'Bliss' (Liggins et al. 2011: 204-08). ${ }^{3}$

My purpose here will be to show that apart from straddling genres, du Maurier's short fiction displays her ability to work across media, an ability that extends beyond cinema to other art forms, namely, photography. Such a claim will amount to show that far from being merely 'a woman's writer of romance' - as the fiction market positioned her - (Liggins et al. 2011: 204), du Maurier is a short story writer who deserves attention, especially because of the intermedial quality of her writing. In order to prove my point, I will focus on 'The Little Photographer', initially published in 1952 by Victor Gollancz in Great Britain in The Apple Tree. ${ }^{4}$

My study of intermediality falls into the third category identified by Irina Rajewsky who makes a distinction between 'medial transposition', 'media combination' and 'intermedial references' (2005: 51-52). ${ }^{5}$ My focus being on a short story, a literary and verbal medium, intermediality will be taken in the sense of intermedial references, that is, a literary work referring to another medium - here, photography. Intermediality, in that case, designates 'just one medium $[\ldots]$ that is materially present. Rather than combining different medial forms of articulation, the given media-product thematizes, evokes, or imitates elements or structures of another, conventionally distinct medium through the use of its own media-specific means' (Rajewsky 2005: 53). It implies a crossing of media borders but what Rajewsky calls the 'as if' character of the intermedial references, 'the illusion' they generate 'of another medium's specific practices' (2005: 53) - here, photography's specific practices - must be taken for granted from the start. On that basis, the relation between the verbal and the photographic in 'The Little Photographer' can be explored as well as the way du Maurier expands photography's potential. 
The affinities between the art of photography, as practiced at the time, in the immediate post-war years, and narrative skills will be examined in the selected short story. Beyond the motif of photography and the visual qualities of the narrative, the mediating function of photography within the narrative will first be analysed. The manipulative skills of the photographer and the narrator will then be confronted and the dialogue between the art of photography and the art of writing will be explored. Finally, du Maurier's ability to work across media and texts, the fruitful intersection of photography and short fiction together with the intertextual echoes the short story is interwoven with, will be shown to reverberate on her perception and (re)definition of modernism.

\section{The mediating function of photography}

Initially, the short story 'The Little Photographer' can be read as a romance between the Marquise, who leads the leisurely life of the rich, and a photographer, Monsieur Paul, who has a small shop in a French seaside resort where she spends her holidays with her two daughters and their governess. She is beautiful; he is a cripple. She is haughty; he is humble. Fascinated by her beauty, he falls in love with her; bored with her dull life and her lonely holidays, she decides to have an affair with him. However, the love story turns sour when, the holidays coming to a close, Monsieur Paul voices his desire to live close to her, which she refuses; he then threatens to show the photographs that he took of her to her husband. Seized by panic, she pushes him from the cliff where they have been meeting every afternoon. If the inquest concludes the death was accidental, the Marquise will be plagued throughout her life by her lover's sister, who blackmails her with the photographs that he has taken during their afternoon meetings. Rather than focusing on the haunting process - the haunting quality of the incriminating photographs, for instance - as she does in Rebecca (1938), du Maurier explores here the function that the photographic medium plays in a verbal fiction.

Du Maurier proceeds by photographic saturation, thus endowing the short story and its fairly trivial plot, with complexity. Photography first appears in the short story as a structural motif and catalyst of the plot. It is through photographs that the two characters meet: the Marquise first meets Monsieur Paul when she takes a film to be developed to his shop; they meet again when she invites him to come to her hotel to take photographs of herself and her children. Under the pretext of taking photographs, she goes walking along the cliff where he himself spends his afternoons taking photographs. Finally, photographs will be the means through which the photographers' sister will blackmail the Marquise: they will be the embodiment and the mediators of her guilt. Although photographic images are never materially reproduced and appear in absentia within the text, they literally inhabit it. In that respect and using the classification made by Rajewsky, the short story can be described as intermedial in the narrow sense of the word, that is, as displaying intermedial references, the literary text referring to photography.

More interestingly, a more dynamic form of intermediality can be found in the short story. Rather than being simply juxtaposed, the art of photography and the art of writing, two conventionally distinct media, are articulated within the narrative. The short story thus fits Higgins's definition of intermediality, in his pioneer (1966) essay, as referring to works 'in which the materials of various [...] art forms are "conceptually fused" rather than merely juxtaposed" 
6. A good example of such a modernist technique of characterization is Clarissa Dalloway, a multifaceted character who is compared, in Woolf's Mrs Dalloway, to a diamond.
(Vos 1997: 325). Like photography, the narration in 'The Little Photographer' relies on seeing. Internal focalization is used throughout the narrative, so that we see everything though the eyes of the Marquise. However, her free indirect discourse is in the third person and is interspersed with narration, both devices pointing to the presence of an anonymous narrator in the background. The anonymous narrator captures the Marquise at different moments in various places and in different moods, different lights and postures: 'on her chaise-longue on the balcony of the hotel' (du Maurier [1952] 2004: 160), combing her hair before the mirror, dressing, having lunch on the terrace, etc. She is now contented, now dissatisfied, now excited by the look of admiration in men's eyes, now bored: the narrator thus reveals the various facets of the character.

Similarly, the photographer, who is said to be an artist, and more talented than most Parisian photographers, takes photographs of the Marquise in various postures: 'on the balcony, her arms around the two children' (du Maurier [1952] 2004: 173) or on the chaise-longue, 'leaning back against the cushion' (du Maurier [1952] 2004: 175): 'she permitted Monsieur Paul to take one photograph, then another, then another' (du Maurier [1952] 2004: 175). He also takes multiple snapshots of her on the scene of their lovemaking: 'He photographed her as she sat, [...] so that he had shots of her from every angle, full-face, profile, three-quarter' (du Maurier [1952] 2004: 181). The snapshots read as signs of his admiration and love for the Marquise, as tokens of his humility and a homage to her beauty.

A parallelism is thus suggested between the photographer and the narrator who both choose to reveal their subject as multifaceted, in a truly modernist, almost Woolfian, fashion. ${ }^{6}$ Like Monsieur Paul, the narrator has a photographic eye and the narrative can be described as a series of snapshots the focal point of which is the Marquise, as in Monsieur Paul's photographs. Photography and narration thus appear to develop a similar method and pursue a similar aim, away from monolithic portrayal. The narrator catches his character unawares, in private intimate moments, in her bedroom, for example, and the photographer does the same in unposed photographs, taken while his subject is lying half-asleep in the bracken. The narrator makes his character come to life through her internal monologue and her silent observations of her surroundings, just as the photographer makes his subject come to life, not so much in the conventional posed photographs with her children - 'a tableau, ready set' (du Maurier [1952] 2004: 173) - as in the photographs that he himself arranges, placing her hand or her chin to his own liking (du Maurier [1952] 2004: 173), or, more significantly, in the unposed photographs that he takes. If the narrator's and the photographer's ways of seeing are similar, they are at odds with the Marquise's own way of seeing. Indeed, the Marquise sees the photographer's face 'framed in a cloud of dark curled hair' (du Maurier [1952] 2004: 169): the framing may suggest a photographic eye; however, every time she looks at him, she sees him in that way (du Maurier [1952] 2004: 179), thus displaying a monolithic appraisal of her subject. Her gaze tends to freeze her subject. Its petrifying power reads as a metatextual metaphor of the type of gaze that the artist refuses, a form of seeing that would lead to monolithic narration and to photographs that freeze their subjects instead of capturing them, recreating them and giving them life in the process. It is also a metaphor of the Marquise's relation to Monsieur Paul: she sees him as a toy and their relation as a mere pastime or short-lived game (as she writes to a friend, 'I am amusing myself as usual, and without 
my husband, bien entendu!' [du Maurier (1952) 2004: 184]). Hers is a lethal form of gaze that foreshadows her murder of the photographer. On the whole, the function of photography, as represented through Monsieur Paul's own art, is made clear: photography doubles the narrative, which borrows its method of characterization from modernist writing; it further exposes and mediates the narrative choices, thus acting as a true medium.

\section{Photography, narration and manipulation}

This seems to point at an irenic collaboration between the two media. But du Maurier complicates the intermedial relation between the two art forms and superimposes an agonistic relation onto the first. I will argue that through a similar method, the two media manage to produce two antagonistic discourses.

The method both narration and photography use is that of manipulation. From the beginning to the end of the narrative, the narrator manipulates the reader, making him or her believe that the Marquise is the villain of the story and the photographer her victim. We are led to feel compassion for the disabled photographer who is club-footed: 'he too was crippled, like his sister. His right foot was encased in a high-fitted boot' (du Maurier [1952] 2004: 172); we feel for him when his dignity is wounded by the spiteful words of the haughty disdainful Marquise who, visiting his shop, 'kept him there by her side, treating him with condescension, with a sort of hauteur, even finding fault with certain of the proofs' (du Maurier [1952] 2004: 185). Above all, we witness the cruel murder of the photographer whom she pushes without any qualms from the cliff:

He stooped, by the opening at the cliff's edge, to pick up his stick, and as he did so the terrible impulse was born in her, and flooded her whole being, and would not be denied. Leaning forward, her hands outstretched, she pushed his stooping body. He did not utter a single cry. He fell, and was gone.

(du Maurier [1952] 2004: 193)

and we conclude to her guilt and his innocence. It is the very conclusion Margaret Forster, in her biography of Daphne du Maurier comes to, noting 'the coldness of the woman, her contempt for the poor photographer, her ruthlessness' ([1993] 1994: 258), which leads her to state that 'The Little Photographer', together with the other short stories in The Apple Tree,

showed a shift in the balance of power between the sexes which [the author] had been working out for some twenty years now in her novels. The women were no longer pathetic and exploited, the men no longer always powerful and dominant.

(Forster 1994: 260)

However, once we start thinking of the short story in intermedial terms, we realize that the photographer is also a manipulator. In spite of his humble posture that shows repeatedly in his way of looking at her, 'with humility, with reverence' and 'adoration in his eyes' (du Maurier [1952] 2004: 170) as well as 'devotion' (du Maurier [1952] 2004: 176), the photographer is the one who takes the initiative when taking photographs on the cliff: 'He photographed her as she sat, lazily nibbling at a stem of grass, and it was he who moved, now here, now 
7. The reference is to Mikhail Bakhtin's carnivalesque as exposed in Problems of Dostoevsky's Poetics ([1929] 1984a) and later, in Rabelais and His World ([1929] 1984b) there' (du Maurier [1952] 2004: 181) or later, he takes photographs of her as 'she lay back in the bracken and closed her eyes' (du Maurier [1952] 2004: 186). He is the active one while she is lying passive and abandoned in the bracken; he is, to use Roland Barthes's word, the Operator (Barthes 1980: 51). The photographer is in the position of the voyeur ('his eyes, so solemn, brown, tender, [...] like the eyes of a gazelle' [du Maurier (1952) 2004: 169] keep 'gaz[ing] upon her' [du Maurier (1952) 2004: 173, 174] and 'fix[ing] upon her', almost as an acid would [du Maurier (1952) 2004: 182]) but also in a position of power, and his camera is the instrument of his power. Through picture-taking, and what we could call its carnivalesque power, ${ }^{7}$ the social hierarchy is reversed: the social superior, the Marquise, becomes the dominated one. As Susan Sontag remarks, 'the camera is a kind of passport that annihilates [...] social inhibitions, freeing the photographer from any responsibility toward the people photographed.' (2013: 557) While behaving in a tender and humble way, he in fact masters the whole situation, just as he subtly induced her to come for a walk on the cliff to his little hiding place and let herself be photographed naked while letting her think she was in charge and leading the game. The photographer proves cunning and diabolical and displays only a semblance of submission. The photographs that he takes are in fact instrumental in submitting his lover and later on, in blackmailing her ('As soon as your husband comes to fetch you I will tell him everything. I will show him the photographs' [du Maurier (1952) 2004: 192]) and enslaving her for life, through his own sister's threat to show the prints to the police (du Maurier [1952] 2004: 204). Even if the Marquise is finally responsible for the photographer's death, she only enjoyed an illusion of power in her affair with him ('a sense of power' [du Maurier (1952) 2004: 171] and 'triumph that she was in command of the situation' [du Maurier (1952) 2004: 181]) and will remain a victim of his manipulative skills. She is also a woman who is objectified through his use of the camera and symbolically murdered - the blackmailing only reiterating the symbolic 'photographic' murder.

About twenty years before Sontag started publishing her essays on photography, du Maurier explores both the ideological power of picturetaking and its perverseness; she shows, as Sontag will phrase it, that 'there is an aggression implicit in every use of the camera' ([1973] 2013: 532) and that 'to photograph is to appropriate the thing photographed' ([1973] 2013: 529). For her, as for Sontag,

to photograph people is to violate them, by seeing them as they never see themselves, by having knowledge of them that they can never have; it turns people into objects that can be symbolically possessed. Just as a camera is a sublimation of the gun, to photograph someone is a subliminal murder - a soft murder.

([1973] 2013: 538)

In La Chambre Claire (Camera Lucida), Barthes will reassert that there is an intrinsic relation between photography and death (1980: 22).

Photography thus produces, in 'The Little Photographer', an ironic counter-discourse to narration. If the outcome of the plot and the roles of murderer and victim first seem crystal clear, taking into account the role of photography makes the reader reassess them and question the transparency of narration as fallacious. In the process, photography becomes a medium, generating as it does a counter-narrative. Together, the photographic and the verbal make the short story more complex and ambiguous, blurring the roles of villain 
and victim, the lines between domination and submission and on the whole, giving more depth to the characters while creating irony. We could say that in a way, the two media together embody the duplicity of meaning inherent to irony where the implicit meaning differs from the ostensible one. The counter-narrative that the photographic medium produces can also be analysed as the negative to the positive the verbal narrative would be. Hence, the relation between the two media appears to be a photographic one, if we keep in mind the silver photography of the time based on the development of negatives. We thus come to the following paradoxical conclusion: in spite of the supremacy of the verbal to which photography, photographs and the photographer owe their virtual existence, the photographic asserts its power and turns the short story into a photographic form.

\section{Du Maurier vs modernism}

Working across two media, du Maurier writes an ambiguous ironic short story worthy of the best modernist short story writers. As Müller suggests in his definition of intermediality, the co-existence of different media opens new dimensions of experience to the recipient (Müller 1996). Here, photography and writing combine to tickle the reader's curiosity, create ambiguity and make him or her re-read the story and go on pondering about it long after he or she has finished reading it. They emphasize ambiguity and produce the same type of reading as modernist texts do. Du Maurier herself hints at her modernist legacy through a recurring metaphor, that of the dragonfly, which discreetly connects her short story to Virginia Woolf's 'Kew Gardens'. While Monsieur Paul takes pictures of her in their little hiding place on the cliff, the Marquise gazes at 'a glittering, shivering dragon-fly', which had 'settled on her hand'; just as Simon, in 'Kew Gardens', remembers thinking, when he was in love with Lily, that 'if the dragon-fly settled on the leaf she would say "yes" at once' (Woolf [1919] 1991: 91), the Marquise thinks that 'she must look somewhere else, or the dragon-fly would go' (du Maurier [1952] 2004: 182). In both cases, the dragonfly is used as a metaphor of desire, a recurring one in du Maurier's short story: 'There was no sense of time to the long, languorous afternoon. Just as before the dragon-flies winged about in the bracken' (du Maurier [1952] 2004: 186). With this discreet allusion, du Maurier not only shows that Katherine Mansfield was not her only modernist source of inspiration, as critics would have it, ${ }^{8}$ but also adds another layer to the intermedial process, recovering the intertextuality from which it derives. ${ }^{9}$ She mainly, if implicitly, points out that the modernist legacy has to do with photography, writing with light - its etymological meaning - having transformed the verbal medium - writing with ink and words - into a photographic one.

In 'The Little Photographer', du Maurier creates an original form of intermediality between writing and photography where photography plays a double role, in keeping with its double, negative and positive, nature - a negative, once developed, turning into a positive image: it now doubles and exposes the narrative choices, now produces a counter-narrative. Where Rajewsky states that intermedial references 'obviously have an effect on the overall illusion generated by a given text' and 'can work to undermine this illusion or promote it' (2005: 55), du Maurier shows they can do both, thus emphasizing the ambivalent nature of intermediality. Furthermore, by appropriating modernist techniques, such as characterization, ambiguity and irony, du Maurier implicitly rereads literary modernism as being indebted to
8. See Liggins et al. (2011: 205). Margaret Forster also mentions that du Maurier read a lot of Mansfield

9. See Rajewsky (2005: 47) 
10. We could add with Leena Eilittä that intermedial studies have 'contributed to the liberation of literature - along with other art forms - from an isolated position in the established scholarly landscape with its clear-cut borderlines between disciplines' (2012: vii).

11. Jacobs was one of the first critics to bring to bear visual culture on literary modernism. or 'remediated' by photography and shows that, as Gaudreault and Marion argue, 'it is through intermediality, through a concern with the intermedial, that a medium - [here, literature] - is understood' (2002: 15)..$^{10}$ If du Maurier, by resorting to modernist techniques, suggests that there may be affinities between modernist writing and photography, she more forcefully points out, by granting it a privileged role, that photography may have been instrumental in changing the modernist paradigms of vision to which she is indebted and that modernist writing is primarily a photographic art - thus anticipating on recent revisions of modernist literature 'as responsive to a broader set of influences than the narrow and often purely formally conceived aesthetic sphere' (Jacobs 2001: 5). ${ }^{11}$ She thus gives the reader an incentive to pursue intermedial studies and reread modernist short stories in their light.

\section{REFERENCES}

Bakhtin, M. M. ([1929] 1984a), Problems of Dostoevsky's Poetics (ed. trans. Caryl Emerson), Minneapolis, MN: University of Minnesota Press.

__ ([1929] 1984b), Rabelais and His World (trans. Hélène Iswolsky), Bloomington, IN: Indiana University Press.

Barthes, R. (1980), La Chambre Claire, Paris: Seuil, Les Cahiers du cinéma.

_ (1981), Camera Lucida (trans. Richard Howard), New York: Hill and Wang.

Bowen, E. ([1936] 1950), 'The Faber book of modern short stories', in E. Bowen (ed.), Collected Impressions, New York: Alfred A. Knopf, pp. 38-46.

Eilittä, L. (ed.) (2012), Intermedial Arts. Disrupting, Remembering and Transforming Media, Newcastle-upon-Tyne: Cambridge Scholars.

Forster, M. ([1993] 1994), Daphne du Maurier, London: Arrow Books.

Gaudreault, A. and Marion, P. (2002), 'The cinema as a model for the genealogy of media', Convergences, 8:4, pp. 12-18.

Higgins, D. (1966), 'Intermedia', Something Else Newsletter, 1:1, pp. 1-4.

Jacobs, K. (2001), The Eye's Mind: Literary Modernism and Visual Culture, New York: Cornell University Press.

Liggins, E., Maunder, A. and Robbins, R. (eds) (2011), The British Short Story, Basingstoke: Palgrave Macmillan.

Maurier, D. du ([1952] 2004), 'The Little Photographer', in D. du Maurier (ed.), The Birds and Other Stories, London: Virago, pp. 160-205.

Müller, J. E. (1996), Intermedialität: Formen moderner kultureller Kommunikation, Münster: Nodus.

Rajewsky, I. O. (2005), 'Intermediality, intertextuality, and remediation: A literary perspective on intermediality', Intermédialités: Histoire et théorie des arts, des lettres et des techniques (Intermediality: History and Theory of the Arts, Literature and Technologies), 6, pp. 43-64.

Reynier, C. (2013), 'The outrageousness of outrage in Daphne du Maurier's "Monte Verità"', Etudes Britanniques Contemporaines, 45, http:// ebc.revues.org/577. Accessed 25 October 2016.

Sontag, S. ([1973] 2013), 'Plato's Cave', in David Rief (ed.), Essays of the 1960s and 70s, New York: The Library of America, pp. 529-45.

(2013), 'America, seen through photographs, darkly', in David Rief (ed.), Essays of the 1960s and 70s, New York: The Library of America, pp. 546-61. 
Vos, E. (1997), 'The eternal network. Mail art, intermedia semiotics, interart studies', in Ulla-Britta Lagerroth, Hans Lund and Erik Hedling (eds), Interart Poetics: Essays on the Interrelations of the Arts and Media, Amsterdam: Rodopi, pp. 325-36.

Woolf, V. ([1919] 1991), 'Kew Gardens', The Complete Shorter Fiction, in S. Dick (ed.), London: Triad/Grafton Books, pp. 90-95.

Zižek, S. (2005), 'Are we allowed to enjoy Daphnée [sic] du Maurier?', http:// www.lacan.com/zizdaphmaur.htm. Accessed 25 October 2016.

\section{SUGGESTED CITATION}

Reynier, C. (2018), 'Beyond cinema: Daphne du Maurier's intermedial experiments in "The Little Photographer" (1952)', Short Fiction in Theory E Practice, 8:1\&2, pp. 89-97, doi: 10.1386/fict.8.1-2.89_1

\section{CONTRIBUTOR DETAILS}

Christine Reynier is professor of English Literature at Montpellier 3, France. She has published on major modernist writers, edited journals on Virginia Woolf (Journal of the Short Story in English [JSSE] 50) and published Virginia Woolf's Ethics of the Short Story (Palgrave, 2009). Other publications include 'Musing in the museums of Ford's Provence', Word \& Image, 30:1 (13 May 2014); 'Virginia Woolf's ethics and Victorian moral philosophy', Philosophy and Literature, 38/1 (April 2014) and 'Reframing the modernist short story' (with M. Duyck and M. Basseler), JSSE 64 (Spring 2015). Her book (with B. Coste and C. Delyfer) on Reconnecting Aestheticism and Modernism was published by Routledge in 2017.

Contact: Department of English, University Paul Valéry Montpellier 3, EMMA EA741, F34000, Montpellier, France.

E-mail: christine.reynier@univ-montp3.fr

Christine Reynier has asserted her right under the Copyright, Designs and Patents Act, 1988, to be identified as the author of this work in the format that was submitted to Intellect Ltd. 